Available online at : http://journal.unj.ac.id/unj/index.php/gjik

Gladi : Jurnal Ilmu Keolahragaan 09 (02) 2018, 119 - 133

Permalink/DOI: https://doi.org/10.21009/GJIK.092.05

\title{
PENGEMBANGAN PEMBELAJARAN RENANG GAYA BEBAS BERBASIS MULTIMEDIA INTERAKTIF
}

\author{
Mashud ${ }^{1}$, Widiastuti ${ }^{2}$ \\ Fakultas Ilmu Pendidikan Lambung Mangkurat \\ JL. Taruna Praja Raya Komplek Kampus JPOK FKIP Unlam Kota Banjrabaru \\ *Corresponding Author. Email: mashud@unlam.ac.id
}

\begin{abstract}
Abstrak : Penelitian bertujuan untuk mengembangkan pembelajaran renang gaya bebas berbasis multimedia interaktif untuk mahasiswa program studi pendidikan jasmani dan memperoleh data empiris tentang efektifitas produk hasil pengembangan terhadap peningkatan hasil belajar kemampuan renang gaya bebas mahasiswa. Penelitian ini menggunakan metode research and development $(R \& D)$ dari Borg and Gall yang terdiri dari 10 langkah. Subyek ujicoba dalam penelitian ini adalah mahasiswa PJKR. Subyek ujicoba kelompok kecil mahasiswa PJKR FKIP ULM berjumlah 15 orang, subyek ujicoba kelompok besar 120 mahasiswa. Sedangkan sampel peneltian untuk uji efektifitas produk berjumlah 90 orang mahasiswa Hasil penelitian pengembangan ini berupa buku teks dan aplikasi multimedia interaktif pembelajaran renang gaya bebas berbasis android. Untuk mengetahui efektifitas produk, peneliti mengujikan menggunakan desain penelitian eksperimen kepada 45 orang mahasiswa selama 4 bulan/ 16 kali pertemuan dengan design eksperimen the one group control pretest-posttest design, menghasilkan bahwa nilai dari Ztabel > Z hitung (89> $-5,7622$ ), maka terdapat perbedaan yang signifikan antara sebelum mendapat perlakuan dan sesudah perlakuan. Jadi bisa dikatakan bahwa produk pengembangan efektif meningkatkan hasil belajar kemampuan renang gaya bebas mahasiswa.
\end{abstract}

Kata Kunci: Pembelajaran renang gaya bebas, multimedia interaktif.

Abstract : The aims of this research are, first to develop crawl learning process based on multimedia interactive learning in the subject of Theory and Practice (T\&P); second, to get empirical data about the effectiveness result in a crawl development program of the Student who are majoring Education of body health and Recreation (PJKR). This research used Research and Development (R\&D) method from Borg and Gall that consist of 10 steps development. The subject of this research is taken from students of PJKR, included the students who are majoring PJKR in FKIP, PJKR in STKIP Setia Budhi and PJKR in Kusuma Negara. The development product has been verified that it increase a capability result of the student in crawl learning process, included 45 students as a subject in experiment group and 45 students as a control group. The verification process of this development product is taken for about one semester ( 6 months). Then, the result of the study finds that a percentage of $Z$ table $>\mathrm{Z}$ quantification $(89>-5,7622$ ), it means there is a significant differences of the result between pretest training and posttest training. So, it can be concluded that the development program is effective to increase the skill of students who are learning a crawl method.

Key Words: Crawl Learning Development, Multimedia Interactive Learning, R\&D Method, T\&P Subject. 


\section{PENDAHULUAN}

Tidak bisa kita pungkiri jaman sudah berubah, manusia jaman sekarang lebih akrap dengan laptop/ computer, handphone dan perangkat lain yang berbasis digital baik versi on-line maupun of-line. Perubahan pola ini akhirnya berangsur-angsur meninggalkan pola konvensional. Sama seperti bidang lainnya, peranan perangkat digital juga amat erat kaitannya dengan dunia pendidikan. Terutama penggunaan laptop/ computer, dalam pembelajaran maupun dalam peneyelesaian administrasi dan birokrasi pendidikan. Selain itu, komputer mampu untuk berinteraksi secara cepat dan akurat, bekerja dengan cepat dan tepat serta mampu menyimpan data dalam jumlah besar dan aman.

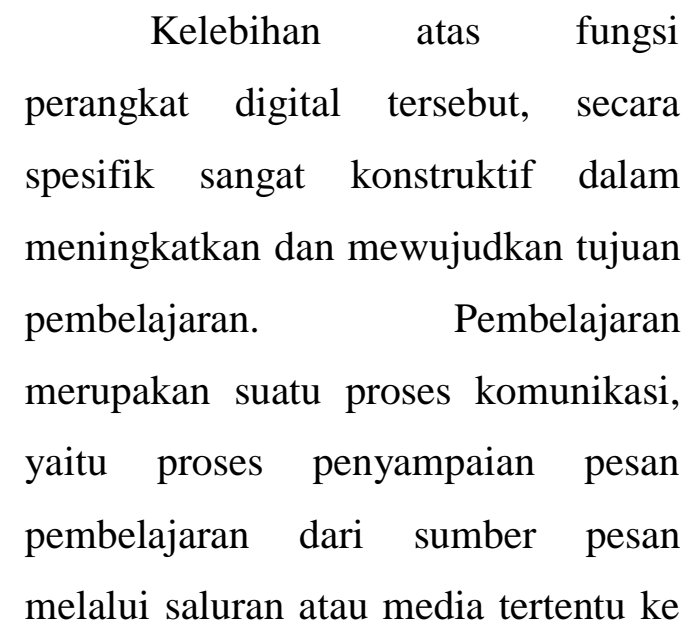

penerima pesan (Dwiyogo, 2011:229). Untuk itu pembelajaran akan lebih menarik, efektif dan praktis apabila memanfaatkan perangkat digital tersebut terutama apabila dipergunakan sebagai media pembelajaran.

Media pembelajaran adalah media, alat, atau teknik yang digunakan dalam proses belajar mengajar dengan maksud agar proses interaksi komunikasi edukasi antara guru dengan siswa dapat berlangsung secara tepat guna dan berdaya guna. Arsyad (2003:29) membagi media pembelajaran menjadi 4 (empat) bagian, yaitu media hasil teknologi cetak, media hasil teknologi audio visual, media hasil teknologi computer, dan media hasil gabungan teknologi cetak dan komputer. Sedangkan multimedia dijelaskan oleh Mayer (2001) adalah media yang memptresentasikan dua unsur yaitu teks (lisan atau tercetak) dan gambar (ilustrasi, foto, animasi dan atau video. Ditambahkan oleh Suyanto (2003) multimedia adalah alat yang dapat menciptakan presentasi yang dinamis yang mengkombinasikan teks, grafik, 


\section{Gladi Jurnal Ilmu Keolahragaan, 09 (2), Oktober - 121}

Mashud, Widiastuti

animasi, audio, dan gambar serta video. Dari beberapa definisi tentang media dan multimedia tersebut di atas, maka bisa ditarik sebuah kesimpulan bahwa multimedia adalah penggabungan beberapa unsur media yang terdiri dari teks, grafik, animasi, audio, dan video, sehingga dalam penerapannya dalam pembelajaran multimedia akan melibatkan berbagai indera yang meliputi indera penglihatan, dan pendengaran.

Sedangkan Budinanto, membagi multimedia menjadi tiga jenis, yaitu 1) multimedia interaktif adalah pengguna dapat mengontrol apa dan kapan elemen-elemen multimedia akan dikirimkan atau ditampilkan; 2) multi media hiperaktif, adalah multimedia yang mempunyai suatu struktur dari elemen-elemen terkait dengan pengguna yang dapat mengarahkannya; 3) multimedia linier, adalah pengguna hanya menjadi penonton dan menikmati produk multimedia yang disajikan dari awal hingga akhir. Dari uraian tentang definisi media, multimedia di atas, bisa diartikan bahwa multimedia interaktif adalah penggabungan beberapa unsur media yang terdiri dari teks, grafik, animasi, audio, dan video, yang dalam penggunaanya dapat dikendalikan oleh pengguna.

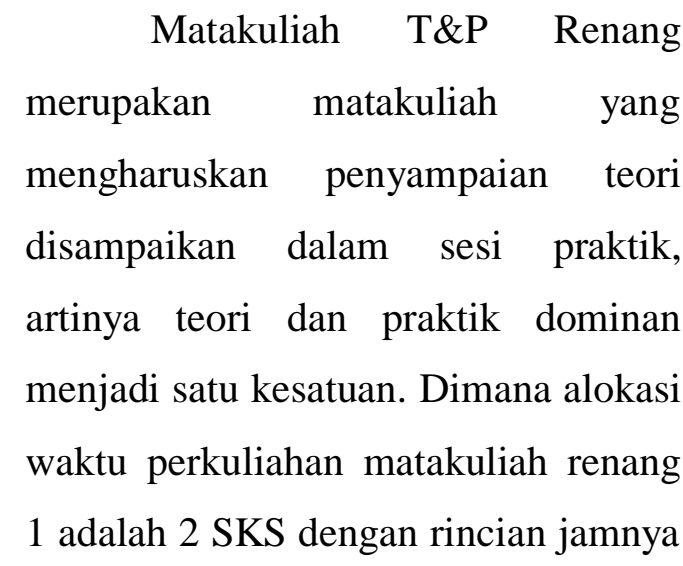
adalah 100 menit tatap muka, 100 menit tugas terstruktur dan 120 menit belajar mandiri (Permendikbud No 29 Tahun 2014: pasal 16). Oleh karena itu alokasi waktu jam perkuliahan sangatlah mendukung dalam mewujudkan capaian pembelajaran matakuliah renang. Tuntutan capaian pembelajaran matakuliah renang tidak hanya mengarah pada kemampuan renang saja, melainkan capaian pembelajaran menuntut mahasiswa harus menguasai ranah sikap yang konstruktif terhadap kemajuan jaman, ranah pengetahuan dan ranah keterampilan. Secara utuh capaian pembelajaran matakuliah renang menjadikan lulusannya setara dan siap 
sebagai tenaga kerja profesional untuk menopang terwujudnya tenaga guru PJOK yang professional dan kompeten.

Untuk mewujudkan capaian pembelajaran matakuliah renang, tentunya harus dibarengi proses pembelajaran yang berkualitas yang mampu menfasilitasi segala kebutuhan dalam pembelajaran. Kebutuhan pembelajaran pada pendidikan tinggi adalah bukan hanya pada terciptanya hasil pembelajaran yang berupa nilai, melainkan lebih dari itu, proses pembelajaran dipandang lebih bermakna tinggi, karena asumsi umum mengatakan segala sesuatu apabila diawali dengan proses yang baik maka dengan sendirinya berdampak pada hasil yang baik pula, dan sebaliknya.

Hasil survei dan pengalaman peneliti, masalah besar dalam pembelajaran renang yang terjadi sampai saat ini adalah pembelajaran terlalu terfokus pada hasil dan mengabaikan proses pembelajaran itu sendiri. Sehingga yang terjadi interaksi pembelajaran dominan seperti melatih pada suatu cabang olahraga. Peran dosen dominan mengajar/ memberi informasi, mahasiswa mendengarkan, menyimak dan mempraktikkan. Interaksi pembelajaran terkesan kaku meskipun terkadang dibuka sesi pertanyaan dan pembahasan, yang pada akhirnya mahasiswa yang belajar menjadi pasif dan cenderung menjadi obyek serta kurang mampu berperan aktif dalam pembelajaran. Sedangkan kita ketahui bersama bahwa ukuran keberhasilan pembelajaran secara umum termasuk pembelajaran renang adalah proses terjadinya interaksi antara mahasiswa yang belajar dengan dosen yang membelajarkan. Bukan semata-mata terletak pada pengajar yang menyampaikan informasi (mengajar). Dengan demikian, diperlukan inovasi dan rekayasa model pembelajaran dan media pembelajaran. Karena dosen bukan satu-satunya sumber belajar, dosen/guru hanya sebagai salah satu bagian dari sumber belajar. Semua sumber belajar dirancang agar dapat mendorong prakarsa dan proses belajar menjadi lebih efektif, efisien dan menarik agar mahasiswa yang belajar tidak mudah bosan/ jenuh untuk terus belajar. Oleh karena itu, fungsi dosen/ guru berubah 


\section{Gladi Jurnal Ilmu Keolahragaan, 09 (2), Oktober - 123}

Mashud, Widiastuti

kearah dosen/guru sebagai pengelola pembelajaran.

Memperkuat permasalahan
yang terjadi dalam perkuliahan
khususnya matakuliah T\&P Renang 1,
peneliti menghimpun melalui analisa
kebutuhan pada mahasiswa dengan
memberikan pertanyaan kepada
mahasiswa, "apakah perlu

pembaharuan penerapan model dan media pembelajaran yang berbasis teknologi informasi” sekita 95\% mahasiswa menyatakan sangat perlu dan $5 \%$ mahasiswa tidak memberikan pendapat. Dari sedikit survei melalui wawancara di kelas saat perkuliahan, peneliti menyimpulkan sangat dibutuhkan bentuk pengembangan model pembelajaran renang berbasis teknologi informasi atau model pembelajaran yang sesuai dengan kemajuan jaman.

Atas permasalahan yang terjadi dan hasil analisis kebutuhan dengan mahasiswa peneliti menyimpulkan bahwa dalam perkuliahan yang mampu memfasilitasi kebutuhan mahasiswa dalam belajar saat ini adalah mengembangkan model pembelajaran yang berbasis multimedia interaktif.
Karena penelitian pengembangan akan menghasilkan sebuah produk, dan produk tersebut bisa diterapkan sebagai bahan/ media pembelajaran dalam matakuliah renang. Berbasis multimedia interaktif, peneliti bermaksud menonjolkan pada proses pembelajarannya agar mahasiswa bisa belajar dengan memanfaatkan berbagai media, bisa gambar, teks, video, yang semuanya bisa dikendalikan dan dikontrol oleh mahasiswa sesuai kebutuhan dalam belajar. Sehingga interaksi pembelajaran antara dosen dan mahasiswa, mahasiswa dengan mahasiswa, mahasiswa dengan lingkunganya akan terjalin dengan baik dan diharapkan berdampak pada hasil perkuliahan yang mampu mencapai tujuan perkuliahan tersebut. Serta harapan besarnya adalah tercapai profil lulusan yang berkualiatas dan siap menjadi guru PJOK yang kompeten dan professional.

\section{METODE}

Metode penelitian dan pengembangan dalam penelitian ini menggunakan model pengembangan Research \& Development $(R \& D)$ dari Borg dan Gall (2007) yang terdiri dari 
sepuluh langkah, yaitu: 1) analisis kebutuhan dan observasi lapangan, 2) menyusun rencana penelitian, 3) pengembangan produk awal, 4) uji coba tahap awal, 5) revisi roduk awal, 6) uji coba utama, 7) revisi produk, 8) uji utama untuk melihat hasil efektifitas produk, 9) revisi akhir, dan 10) desiminasi dan implementasi.

Subyek penelitian ini adalah mahasiswa program studi pendidikan jasmani kesehatan dan rekreasi (PJKR) yang merupakan mahasiswa calon guru PJOK. Subyek ujicoba kelompok kecil mahasiswa PJKR FKIP ULM berjumlah 15 orang, subyek ujicoba kelompok besar 120 mahasiswa (40 orang mahasiswa dari PJKR STKIP Setia Budhi, 40 orang mahasiswa PJKR Khusuma Negara dan 40 orang mahasiswa PJKR FKIP ULM).
Sedangkan sampel peneltian untuk uji efektifitas produk berjumlah 90 orang mahasiswa (45 orang mahasiswa sebagai kelompok eksperimen dan 45 orang mahasiswa sebgai kelompok kontrol). Teknik pengambilan subyek menggunakan probability sampling teknik simple random sampiling, yaitu pengambilan subyek ujicoba secara acak melalui cara undian, hal ini dikarenakan semua calon subyek atau seluruh populasi adalah dalam keadaan homogen (Sugiyono, 2010: 64).

Jenis data yang dihasilkan berupa data kuantitatif dan data kualititaif. Data kuantitatif diperoleh dengan rancangan penelitian eksperimen berbentuk the one group control pretest-posttest design (Maksum, 2012: 29). 
Tabel 1 Desain Penelitian dalam Uji Efektifitas Model

\begin{tabular}{cccc}
\hline Subjek & Pres-Test & Perlakuan & Post-Test \\
\hline $\mathrm{E}$ & $\mathrm{O}_{1}$ & $\mathrm{P}$ & $\mathrm{O}_{2}$ \\
\hline $\mathrm{K}$ & $\mathrm{O}_{3}$ & & $\mathrm{O}_{4}$ \\
\hline
\end{tabular}

Hipotesis penelitian pada

efektifitas model yang dikembangkan adalah apakah terdapat pengaruh yang signifikan kemampuan renang gaya bebas sebelum dan sesudah diberikan treatment dengan pembelajaran renang gaya bebas berbabasis multimedia interaktif.

Langkah yang dilakukan dalam uji coba ini antara lain; (1) menetapkan kelompok subjek penelitian; (2) melaksanakan pre-test $\left(\mathrm{O}_{1}\right)$; (3) mencoba model yang telah dikembangkan; (4) melaksanakan post-test $\left(\mathrm{O}_{2}\right)$; (5) mencari skor ratarata pre-test dan post-test dan dibandingkan antar keduanya; (6) mencari selisih perbedaan kedua ratarata tersebut melalui metode statistic (uji-t) untuk mengetahui ada tidaknya pengaruh yang signifikan dari penggunaan model.

Besarnya peningkatan kemampuan renang mahasiswa dapat dihitung dari nilai pretest dan posttest menggunakan indeks gain Hake yaitu seperti persamaan berikut.

$$
\begin{aligned}
& \text { Normalitas gain }(<g>) \\
& =\frac{\text { skor posttest }- \text { skor pretest }}{\text { skor maksimal }- \text { skor pretest }}
\end{aligned}
$$

Kriteria yang digunakan untuk menginterpretasikan gain ternormalisasi/N-gain (Hake, 2017).

Tabel 2 Kriteria Gain

\begin{tabular}{cl}
\hline Skor rata-rata & Kriteria \\
\hline$(<\mathrm{g}>)<0,3$ & rendah \\
$0,3 \leq(<\mathrm{g}>)<0,7$ & sedang \\
$0,7 \leq(<\mathrm{g}>)$ & tinggi \\
\hline
\end{tabular}




\section{Gladi Jurnal Ilmu Keolahragaan, 09 (2), Oktober - 126}

Mashud, Widiastuti

\section{HASIL PENELITIAN}

Seperti yang telah dijabarkan pada metode penelitian di atas, bahwa tahapan penelitian pengembangan ini menggunakan tahapan penelitian pengembangan dari Brog and Gall yang terdiri dari (10) sepuluh langkah, adapun langkah tersebut menghasilkan data sebagai berikut.

Pertama, analiisis kebutuhan menghasilkan data bahwa mayoritas mahasiswa menyatakan sangat perlu dan dibutuhkan bentuk pengembangan pembelajaran renang berbasis multimedia interaktif yang sesuai dengan kemajuan jaman.

Kedua, menyusun rencana penelitian dan membuat draft produk pengembangan. Draft produk pengembangan disusun berdasarkan asupan materi perkuliahan matakuliah renang 1 fokus pada renang gaya bebas yang terdiri dari; 1) profil penulis, 2) pembelajaran renang gaya bebas yang terdiri dari (gerakan tungkai, gerakan lengan, gerakan bernafas, dan gerakan koordinasi), 3) E-book, 4) Quis Interaktif pembelajaran renang gaya bebas.
Ketiga, mengujikan draft produk pengembangan pada para ahli (ahli pembelajaran renang, ahli pembelajaran gerak, ahli pelatihan renang dan ahli media). Ahli pembelajaran renang, ahli gerak dan pelatih renang mendapatkan kesimpulan bahwa model pembelajaran renang gaya bebas gaya bebas awalnya berjumlah 27 model gugur 2 menjadi 25 model. Sedangkan ahli media, menghasilkan kesimpulan saran dan masukan pada bentuk produk yang terkait pada keterlaksanaan dan kemenarikan secara multimedia.

Keempat, data hasil masukan dan saran para ahli, selanjutkan peneliti revisi dan perbaiki. Langkah keempat ini merupakan tahap revisi tahap 1.

Kelima, mengujikan produk pengembangan pada uji coba kelompok kecil dengan melibatkan subyek 15 orang mahasiswa. Dari hasil ujicoba kelompok kecil, dapat disimpulkan bahwa keseluruhan model pembelajaran renang gaya bebas layak dipakai dan terdapat beberapa catatan penerapannya, terutama pada penerapan yang membutuhkan alat, luas kolam, dan keberadaana kolam 
renang yang bukan kolam milik pribadi kampus, yang mengharuskan selalu konsolidasi terhadap pengguna lain.

Keenam, langkah ini, merevisi produk berdasarkan saran masukan dan catatan penerapan produk pada skala kecil. Langkah keenam ini merupakan tahap revisi tahap 2 .

Ketujuh, uji coba kelompok besar, dimana produk ini nantinya akan digunakan dan di implementasikan dalam pembelajaran. Subyek penelitian pada ujicoba kelompok besar ini, melibatkan 120 orang mahasiswa yang terdiri dari: 40 mahasiswa dari Prodi. PJKR FKIP ULM; 40 mahasiswa dari prodi. PJKR STKIP Khusuma Negara Cijantung Jakarta Timur; 40 mahasiswa Prodi. PJKR STKIP Setia Budhi Rangkas Bitung Kab. Lebak Provinsi Banten. Atas dasar catatan, saran dan temuan pada uji coba kelompok besar di atas, maka dapat disimpulkan secara keseluruhan model layak dan bisa dipergunakan dalam pembelajaran di matakuliah renang. Namun terkait penerapan ada beberapa catatan, terutama pada kondisi kolam, alat dan sarana renang, tidak semua mahasiswa memiliki fasilitas handpone yang siap dipergunakan terutama terkait data paket internet dan kapasitas memori penyimpanan.

Kedelapan, langkah ini, merevisi produk berdasarkan saran masukan dan catatan penerapan produk pada skala besar. Langkah kedelapan ini merupakan tahap revisi tahap 3.

Kesembilan, uji coba operasional (uji efektifitas produk) uji tahap ini bertujuan untuk mengetahui sejauh mana produk pengembangan mampu memberikan pengaruh atau dampak terhadap hasil pembelajaran pada mahasiswa. Hasil uji efektifitas model adalah dengan melakukan tes unjuk kerja terhadap 45 mahasiswa. Tes unjuk kerja dilakukan di awal sebelum ada perlakukan dan tes akhir setelah mahasiswa mendapatkan perlakuan.

Hasil uji efektifitas model pada kelompok eksperimen, antara tes awal dan tes akhir, Karena nilai dari Ztabel > $\mathrm{Z}$ hitung (89 > -5,7622), maka terdapat perbedaan yang signifikan antara sebelum mendapat perlakuan dan sesudah perlakuan.

Sedangkan hasil uji efektifitas model pada kelompok control antara tes 
awal dan tes akhir, didaptkan kesimpulan bahwa Karena nilai dari Z tabel > Z hitung (89>-5,7171), maka terdapat perbedaan yang signifikan antara sebelum mendapat perlakuan dan sesudah perlakuan

$$
\text { Selanjutnya dilakukan }
$$

penghitungan uji beda antar kelompok yaitu kelompok eksperimen dengan kelompok kontrol khusus pada hasil tes akhir/ postest saja. Adapun tujuan dari uji beda antar kelompok ini adalah untuk mengetahui apakah ada perbedaan hasil belajar kemampuan renang gaya bebas mahasiswa Prodi. PJKR antara kelompok eksperimen yang diberi perlakuan dengan kelompok kontrol/ kelompok pembanding yang mengikuti matakuliah renang seperti biasanya.

Data uji beda antar kedua kelompok tersebut adalah karena nilai z tabel (88.593) lebih besar dari pada $\mathrm{z}$ hitung (-1.82294), maka terdapat perbedaan yang signifikan antara kelompok kontrol dengan eksperimen. Sehingga bisa diambil sebuah kesimpulan bahwa, kemampuan renang mahasiswa Prodi. PJKR kelompok eksperimen atau kelompok mahasiswa yang telah diberi perlakuan model pembelajaran renang gaya bebas berbasis multimedia interaktif lebih baik dari pada kemampuan renang mahasiswa Prodi. PJKR pada kelompok kontrol/ kelompok pembanding.

\section{PEMBAHASAN}

Penelitian ini berawal atas adanya permasalahan dalam pembelajaran pada perguruan tinggi, khususnya pada pembelajaran matakuliah renang di program studi pendidikan jasmani. Dalam pembelajaran sering terlalu berorientasi pada hasil pembelajaran/ nilai akhir cenderung melupakan proses pembelajaran. Permasalahan ini berdampak pada profil lulusan matakuliah renang tersebut, banyak mahasiswa lulus matakuliah renang tetapi kemampuan renangnya masih dipandang kurang, sebagian lulus dengan predikat baik dan betul-betul bisa berenang, namun apabila ditanya bagaiamana proses renang yang baik dan bagaimana cara me,belajarkan pada orang lain, mayoritas masih belum mampu berbuat banyak. Atas sedikit permasalahan ini, peneliti memandang 
perlu untuk membuat pembelajaran renang tercapai tujuan secara utuh (kemampuan renang baik, sikap baik, pengetahuan baik dan yang terpenting mahasiswa mampu membelajarkan renang pada orang lain atau calon muridnya kelak saat menjadi guru PJOK).

Penelitian pengembangan ini telah menghasilkan produk pengembangan pembelajaran renang gaya bebas berbasis multimedia interaktif. Produk hasil pengembangan berbentuk aplikasi multimedia interaktif. Pengembangan produk dalam penelitian ini dilakukan sebagai upaya untuk meningkatkan kemampuan hasil belajar renang gaya bebas mahasiswa PJKR.

Produk pengembangan, juga telah diuji kefektifannya dalam meningkatkan hasil belajar renang gaya bebas mahasiswa, dengan melibatkan 45 mahasiswa sebagai subyek uji coba kelompok eksperimen dan 45 mahasiswa sebagai kelompok control. Uji efektifitas produk peneliti jalankan selama satu semester. Penerapan uji efektifitas produk pengembangan selama satu semester dalam perkuliahan matakuliah renang, peneliti memaksimalkan fungsi multimedia interaktifnya sebagai media dan sumber belajar mahasiswa. Penerapan dalam perkuliahan, produk pengembangan sebagai media/ sumber belajar ini, peneliti pakai sebagai bahan tugas gerak bagi mahasiswa untuk dipraktikkan diluar jam perkuliahan. Hal ini senada dengan pendapat Darmawan (2011:15) mengemukakan bahwa sumber belajar berupa multimedia interaktif memiliki bebrapa kelebihan untuk dipergunakan sebagai media pembelajaran, yaitu 1) dapat digunakan kapanpun dan dimanapun, 2) cakupan luas, 3) terintegrasi dengan sistem lainnya. Kelebihan ini yang nantinya akan mewujudkan filosofi belajar yang dikemukakan oleh Moston dan Ashworth (2013:1) William (2014:8) Arend (2001:3) yang menyatakan bahwa "...belajar adalah proses atau usaha yang dilakukan tiap individu untuk memperoleh suatu perubahan tingkah laku, baik dalam bentuk pengetahuan, keterampilan maupun sikap dan nilai yang positif sebagai pengalaman”. 


\section{Gladi Jurnal Ilmu Keolahragaan, 09 (2), Oktober - 130}

Mashud, Widiastuti

Multimedia interaktif pembelajaran renang gaya bebas diwujudkan dalam versi offline yang dapat dilakukan dan dimulai hanya dengan melakukan satu kali pemasangan dan tidak membutuhkan koneksi internet dalam penggunaannya. Sehingga pemanfaatan multimedia interaktif sebagai media pembelajaran tidak menimbulkan dampak yang menyulitkan bagi mahasiswa yang belajar. Penggunaannya bersifat ekonomis, praktis, dan kondisional. Tidak ada alasan bagi mahasiswa untuk tidak belajar dan berlatih.

Selain penggunaan multimedia interaktif sebagai media pembelajaran dalam usaha memberikan hasil belajar kemampuan renang gaya bebas mahasiswa PJKR yang baik, memiliki peran yang sangat besar. Melalui media pembelajaran, potensi indera mahasiswa yang belajar dapat diakomodasi sehingga hasil belajar akan meningkat. Hal ini sejalan dengan pendapat Frey \& Sutton (2010:492507) Uden \& Campion (2000:1-10) yang menyatakan bahwa salah satu aspek yang diunggulkan mampu meningkatkan hasil belajar adalah bersifat multimedia, yaitu kombinasi dari computer dan video, suara, gambar, music, animasi, teks, grafik, gambar, yang dapat menciptakan presentasi yang dinamis dan interaktif. Adanya kombinasi antara unsur media seperti teks, gambar, video akan mengakomodasi indera mahasiswa yang belajar lebih baik dan lebih menarik.

Media pembelajaran yang dihasilkan juga berupa buku cetak dan buku elektronik yang didesain berbentuk buku literature dan berbentuk PDF. Ini dimaksudkan agar pengguna/ mahasiswa bisa menggunakan sebagai bahan belajar/ sumber belajar/ media pembelajaran dalam berbagai bentuk dan memfasilitasi berbagai macam karakteristik mahasiswa dalam belajar. Mahasiswa yang senang dengan aplikasi multimedia interaktif bisa menggunakannya, mahasiswa yang senang bekajar dengan versi manual/ cetak, mahasiswa juga bisa menggunakannya. Dengan segala bentuk dan versi produk pengembangan ini diharapkan mampu memberikan dampak pada peningkatan hasil hasil 
belajar dan kemampuan renang gaya bebas. Selain itu juga diharapkan mahasiswa sebagai calon guru PJOK disekolah, akan mampu memiliki pengalaman belajar yang bervariasi dan konstruktif dalam mewujudkan proses belajar yang dinamis, proses belajar yang kondusif dan efektif.

Keunggulan produk ini sebagai salah satu alternative media yang layak digunakan untuk meningkatkan hasil belajar dan kemampuan renang gaya bebas mahasiswa adalah 1) materi variasi pembelajaran renang gaya bebas disusun berdasarkan pentahapan gerak dari yang sederhana sampai ke yang komplek, yang mudah sampai ke yang sulit, yang individu samapai ke berpasaangan dan berkelompok, 2) tampilan aplikasi multimedia interaktif, peneliti desain dalam beberapa komponen, diantaranya adalah bentuk gambar, video, teks, dan quiz, 3) produk pembelajaran renang gaya bebas berbasis multimedia interaktif dapat digunakan sebagai media belajar mandiri, 4) produk pembelajaran renang gaya bebas berbasis multimedia interaktif, mudah dibawah kemanamana sehingga dipelajari dimanapun dan kapanpun, 5) produk pembelajaran renang gaya bebas berbasis multimedia interaktif berperan sebagai pelengkap, penguat dan pengingat tentang renang gaya bebas.

Selain adanya keunggulan, produk pengembangan ini juga terdapat beberapa kelemahan dan kekurangan, diantaranya adalah 1) penyusunan variasi pembelajarn renang gaya bebas masih bersifat dangkal, belum spesisik variasi yang menekankan pada pengetahuan teknik renang gaya bebas secara utuh, 2) variasi pembelajarn renang hanya memfasilitasi terjadinya proses pembelajaran yang baik, yang mampu membangkitkan suasana beajar, 3) dan tampilan aplikasi multimedia interaktif masih perlu banyak koreksi dan pembenahan.

Adanya keunggulan dan kelemahan dari produk pengembangan ini, memungkinkan bagi peneliti lain untuk mengembangkan pada tataran yang lebih spesifik, lebih baik, dan lebih menarik. Khususnya pengembangan renang pada gaya-gaya atau teknik yang lain. 


\section{KESIMPULAN}

Berdasarkan hasil penelitian
pengembangan, mulai tahap
perencanaan produk, analisis uji ahli
renang, uji ahli pembelajaran, uji ahli
gerak dan uji ahli media, secara
keseluruhan memberikan penilaian
layak produk ini untuk diterapkan
sebagai media pembelajaran renang
gaya bebas bagi mahasiswa program
studi pendidikan jasmani. Uji coba
pelaksanaan dalam skala kecil dan
skala besar, produk pengembangan
dinyatakan layak dan bisa
dipergunakan dalam pembelajaran
matakuliah renang.

Efektifitas

produk

pengembangan menghasilkan data yang signifikan dapat meningkatkan hasil belajar dan kemampuan renang gaya bebas mahasiswa PJKR dengan data uji beda antar kedua kelompok tersebut adalah nilai z tabel (88.593) lebih dari nilai z hitung (-1.82294), maka terdapat perbedaan yang signifikan antara kelompok kontrol dengan eksperimen. Sehingga bisa diambil sebuah kesimpulan bahwa, kemampuan renang gaya bebas mahasiswa Prodi. PJKR kelompok eksperimen atau kelompok mahasiswa yang telah diberi perlakuan model pembelajaran renang gaya bebas berbasis multimedia interaktif lebih baik dari pada kemampuan renang mahasiswa Prodi PJKR pada kelompok kontrol/ kelompok pembanding.

\section{DAFTAR PUSTAKA}

Arends, R. 2001. Learning To Teach. Toronto: Mc Graw Hill. (online) www.tandfonline.com diakses 07 Januari 2018.

Borg, W.R. \& Gall, M.D. 2007. Educational Research An Introduction, Eighth Edition. New York \& London: Longman.

Budinanto, Iwan, 2015. Multimedia Digital; Dasar teori dan Pengembanganya: Jogjakarta: Andi Offset.

Darmawan, D. 2011. Teknologi Pembelajaran. Bandung: PT. Remaja Rosdakarya.

Frey, B.A \& Sutton, J.M. 2010. A Model Developing Multimedia Learning Project. Merlot Journal Of Online Learning and Teaching. Vol 6 No 2 Juni 2010.

Hake, Six Lessons From The Physics Education Reform Effort. Physic. Education, 1(1): 24-31. http://lajpe.org/sep07/HAKE_F inal.pdf [diakses 4-6-2017]. 
Maksum, Ali. 2012. Metode Penelitian Dalam Olahraga. Surabaya: Unesa Univerity Press,

Mayer, R. E, 2008. Learning and Instruction. New Jersey: Pearson Education, Inc.

Moston, M \& Ashwort, S. 2013. Gaya Mengajar Pendidikan Jasmani. Malang: Wineka Media.

Suyanto, Muhammad, 2003. Multimedia Untuk Meningkatkan Keunggulan Bersaing. Yogjakarta: Andi Offset.
Sugiyono, 2010. Statistik Untuk Penelitian. Bandung: Alfabeta

Uden, L \& Campion, R. 2000. Integrating Modality Theori In Educational Multimedia Desaign Scool of Computing. Staffordshire Univercity.

William, J. H. 2014. Re Constructing Memory: Scool Texbooks and The Imagination of The Nation. The George Washington University. 